\title{
Lignicolous freshwater fungi from China II: Novel Distoseptispora (Distoseptisporaceae) species from northwestern Yunnan Province and a suggested unified method for studying lignicolous freshwater fungi
}

\author{
Luo ZL ${ }^{1,2}$, Hyde KD², Liu JK ${ }^{3,4}$, Bhat DJ ${ }^{5}$, Bao DF ${ }^{1,2,4}$, Li WL ${ }^{1}$ and Su HY ${ }^{1 *}$ \\ ${ }^{1}$ College of Agriculture \& Biological Sciences, Dali University, Dali 671003, Yunnan, P.R. China \\ ${ }^{2}$ Center of Excellence in Fungal Research, Mae Fah Luang University, Chiang Rai 57100, Thailand \\ ${ }^{3}$ Guizhou Key Laboratory of Agricultural Biotechnology, Guizhou Academy of Agricultural Sciences, Guiyang 550006, \\ P.R. China \\ ${ }^{4}$ Department of Entomology and Plant Pathology, Faculty of Agriculture, Chiang Mai University, Chiang Mai 50200, \\ Thailand \\ ${ }^{5}$ 128/1-J, Azad Housing Society, Curca, Goa Velha-403108, India
}

Luo ZL, Hyde KD, Liu JK, Bhat DJ, Bao DF, Li WL, Su HY 2018 - Lignicolous freshwater fungi from China II: Novel Distoseptispora (Distoseptisporaceae) species from northwestern Yunnan Province and a suggested unified method for studying lignicolous freshwater fungi. Mycosphere 9(3), 444-461, Doi 10.5943/mycosphere/9/3/2

\begin{abstract}
This is the second in a series of papers on lignicolous freshwater fungi from China. In this paper, eight fresh collections of asexual morphs of Distoseptispora, isolated from submerged wood in northwestern Yunnan Province, China, are characterized based on morphological characters and phylogenetic analyses of combined ITS, LSU, RPB2 and TEF1 $\alpha$ sequence data. Four new Distoseptispora species (D. cangshanensis, D. obpyriformis, D. rostrata and D. submersa) are introduced, described and illustrated, with notes on their taxonomy and phylogeny. Newly generated molecular data of Distoseptispora fluminicola is also provided. We also provide a unified method for studying lignicolous freshwater fungi to standardize the findings of future Asian studies.
\end{abstract}

Key word - Asexual fungi - Methodology - Phylogeny - Sordariomycetes - Taxonomy

\section{Introduction}

Lignicolous freshwater fungi play an important role in nutrient and carbon cycling, biological diversity and ecosystem functioning in freshwater ecosystems (Palmer et al. 1997, Yuen et al. 1998, Bucher et al. 2004, Vijaykrishna et al. 2005, Hyde et al. 2016a). There have been some studies on lignicolous freshwater fungi in Yunnan Province, China (Cai et al. 2002, Luo et al. 2004, 2016, 2017, 2018, Liu et al. 2015, Su et al. 2015, 2016, Zhu et al. 2016) and in this paper, we deal with the genus Distoseptispora K.D. Hyde, McKenzie \& Maharachch. which belongs to Distoseptisporaceae, Sordariomycetes.

The family Distoseptisporaceae K.D. Hyde \& McKenzie was introduced by Su et al. (2016) with a single genus Distoseptispora to accommodate two Sporidesmium-like species. Yang et al. (2018) emended the description of the genus Distoseptispora which is characterized by 
macronematous, septate, unbranched, olivaceous to brown conidiophores, monoblastic, holoblastic, determinate, terminal conidiogenous cells and acrogenous, olivaceous, brown or yellowish/reddish brown, euseptate or distoseptate conidia, with a basal cell with cross walls and a basal scar. Currently, there are nine species in Distoseptispora with six species known from freshwater habitats (Su et al. 2016, Hyde et al. 2016b, Yang et al. 2018).

We are carrying out a survey on the diversity of lignicolous freshwater fungi along a northsouth gradient in the Asian region (Hyde et al. 2016a) and this is the second in a series of papers on these fungi from China ( $\mathrm{Li}$ et al. 2017). Eight isolates of Distoseptispora species were collected from submerged decaying wood in northwestern Yunnan Province, China. Four new species, viz. Distoseptispora cangshanensis, D. obpyriformis, D. rostrata, D. submersa are introduced based on morphological characters and phylogenetic analyses. Newly generated molecular data of Distoseptispora fluminicola is also provided. As several research groups are looking at freshwater fungi in Asia, we also update the methods for studying lignicolous freshwater fungi, in order to provide a standardized approach.

\section{Methods to study lignicolous freshwater fungi}

\section{Field collection}

Lignicolous freshwater fungi can be found on decaying wood submerged in creeks, dams, lakes, ponds, pools, rivers, streams or swamps (Goh \& Hyde 1996, Hyde \& Goh 1998a, Wong et al. 1998). The woody substrates collected from freshwater habitats are ideally less than $3 \mathrm{~cm}$ in diameter and ca $15 \mathrm{~cm}$ long, thus they can easily be examined under the microscope. These substrates include part of tree trunks, branches, twigs and litter and are variable in size and length. Substrates trapped between stones and rocks in riffles or those submerged at the bottom of freshwater are preferred, as these are more likely to have been in freshwater for long time and support freshwater fungi (Tsui et al. 2003). It is advisable not to collect floating woody substrates as these may support many terrestrial taxa. Species area curves and trend lines of sample size (number of woody substrates) with species richness in previous studies showed that the number of fungi increased quickly at first and then reached asymptote at around 50 samples (Tsui et al. 2000, Ho et al. 2001). The studies carried out by Hyde and co-workers were based on collections of 100 or more woody substrates from Australia, Britain, Seychelles and South Africa, however, the species diversity are similar to those found on 50 samples (Hyde \& Goh 1997, 1998 a, b, Hyde et al. 1998). It is therefore suggested that 50 samples are collected from each selected collecting site (from downstream to upstream of rivers and streams or around lakes, ponds and dams) as 50 is an optimum number for each collection site discovering most diversity.

Submerged wood baits can also be used to investigate the fungal diversity of lignicolous freshwater fungi especially if standardization of the submergence time, type of wood, or the stage of decay is determined (Jones \& Hyde 1988, Sivichai et al. 2000, Tsui et al. 2001). Usually, a native tree should be chosen as wood baits and should be of the same size for standardization. The woody baits must be sterilized by autoclaving at $1.5 \mathrm{kgf} / \mathrm{cm} 2$ at $121^{\circ} \mathrm{C}$ for 15 minutes or alternatively sun dried which avoids changes in the wood structures. Wood blocks are strung together as ladders and submerged at the sites.

In this study, specimens of submerged decaying wood were collected respectively from Nujiang River, Jinsha River and Cangshan Mountain, Yunnan, China.

\section{Incubation}

Specimens of submerged decaying wood should be returned to the laboratory in plastic bags to avoid moisture loss. The samples are further incubated at room temperature in plastic containers or plastic bags with moistened sterilized tissue paper (Tsui et al. 2000).

\section{Morphological studies}

Samples are examined, after incubation, regularly for up to three months using a dissecting 
microscope (Tsui et al. 2003). For sexual morphs and coelomycetous fungi, hand sections of ascomatal structures or pycnidial structures are made using a razor blade (Chomnunti et al. 2014). Thin sections are mounted in distilled water for microscopic study and photomicrography. Ascomata, asci, ascospores, paraphyses or pseudoparaphyses, conidiomata, conidia and conidiogenous structures are examined under compound microscope (such as Nikon ECLIPSE 80i) can be photographed by digital camera (such as Canon 550D) fitted to a compound microscope (Nikon ECLIPSE 80i). Microscopic characters of hyphomycetes (conidiophores, conidia and conidiogenous cells) are captured with a digital camera fitted to a compound microscope. Measurements are made with the Tarosoft (R) Image Frame Work program and images used for figures processed with Adobe Photoshop CS6 Extended version 13.0 software (Adobe Systems, USA).

\section{Single spore isolation}

There are three main groups of lignicolous freshwater fungi, i.e. ascomycetes, coelomycetes and hyphomycetes, which have different types of fructifications. The methods for isolation may therefore be different.

Ascomata/conidiomata are removed from the substrate surface using fine forceps or cut by using razor blade for immersed ascomata/conidiomata. Spore masses are transferred with a sterilized needle or fine forceps to a drop of sterile water on a small glass container or a flamed microscope slide (Chomnunti et al. 2014). For hyphomycetes, using a needle to stick the conidia and avoid touching the substrate, should dislodge conidia that will stick to the needle and can be placed in a drop of water. If the conidia are not easy to stick to the needle, a single fruiting body including conidiophore and conidia can be picked and placed into a drop of water. The drop of water is then examined under a dissecting microscope to confirm that enough of and the correct spores have been transferred.

The agitated spore suspension is then sucked into a sterilized pipette or Pasteur syringe. Small drops are placed on $2 \%$ water agar (WA), potato dextrose agar (PDA) or malt extract agar (MEA) in the centre of pre-marked squares in a grid on the bottom of a Petri dish and incubated at room temperature or in an incubator $\left(25^{\circ} \mathrm{C}\right)$ overnight. After 12 hours, the plates are examined for single germinating spores under a dissecting microscope at high magnification. Germinating spores are transferred separately to at least two new MEA/PDA plates. Spores normally germinate within 12 24 hours and should be transferred immediately by picking up single spores with a small piece of agar using a fine needle (Chomnunti et al. 2014). From our experience, bacteria or moulds will overgrow the Petri dish within three days after single spore suspensions are placed on plates. In this case, the hypha of the germinated spore will be contaminated. Therefore, transfer to fresh plates must be carried out early on. Otherwise, it will be impossible to make sure that single spore cultures of the correct species have been obtained. Four to six spores can be placed at opposite sides of the Petri dish. Some spores should be examined under the compound microscope to confirm the correct spore types or species has been obtained. If identical spores have been picked for the initial Petri dishes, all colonies should be similar.

\section{Preparation of herbarium material}

Herbarium material is essential for describing new species and important to keep records so that published data are verifiable (Chomnunti et al. 2014). Herbarium material should be prepared as early as possible by cutting a small piece of wood containing the single species, rather than depositing samples with multiple species. Ideally, prepare the herbarium specimens from a portion of your sample at the beginning of the study, as with prolonged incubation the taxon may have disappeared. Dried cultures can also be used for herbarium material. All dried material should be placed in containers or herbarium packets, labeled and deposited in an international herbarium. In this study, original samples (dry wood with fungi) are deposited at the herbarium of Cryptogams Kunming Institute of Botany Academia Sinica (HKAS) and Mae Fah Luang University (MFLU). 


\section{Storage of cultures}

The main problem when working with fungal cultures is contamination by other fungi or mites. The risk increases with incubation time. The best way to solve this problem is therefore to deposit pure cultures in more than one culture collection as early as possible and not only when a culture collection number is needed for a publication (Chomnunti et al. 2014). Another method is to add Ivermectin to the agar just before pouring plates. In this study, pure cultures are deposited in Mae Fah Luang University Culture Collection (MFLUCC) and Dali University Culture Collection (DLUCC).

\section{DNA extraction, PCR amplification and sequencing}

The eukaryotic rRNA cistron comprises the $18 \mathrm{~S}, 5.8 \mathrm{~S}$, and $28 \mathrm{~S}$ rRNA genes transcribed as a unit by RNA polymerase I (Schoch et al. 2012), and has been used for fungal diagnostics and phylogenetic analyses for more than 20 years (Begerow et al. 2010, Schoch et al. 2012). Additionally, protein-coding genes are widely used in mycology for phylogenetic analyses or species identification as they are generally superior to rRNA genes for resolving relationships at various taxonomic levels (Schoch et al. 2009, Maharachchikumbura et al. 2016). Tanaka et al. (2015), Liu et al. (2017) included the TEF1 $\alpha$ locus in the multi-gene analyses of Massarineae and Dothideomycetes respectively, which resolved many ascomycete lineages well, and is a marker of good resolution at the generic level and below (Hyde et al. 2017). Maharachchikumbura et al. (2016) used LSU, SSU, RPB2 and TEF1 $\alpha$ sequence data to do the multi-gene analyses to show families and order relationships within the class Sordariomycetes. We suggest that both ribosomal genes and protein genes should normally be sequenced and used in analyses.

In order to make sure the culture is isolated from the correct species and duplicated in the phylogenetic analysis, at least two cultures, ideally isolated from different specimens are needed for each species. In this study, we extracted genomic DNA from fresh fungal mycelium grown on PDA at $25-27^{\circ} \mathrm{C}$ and used a EZ gene TM Fungal gDNA kit (GD2416) to extract DNA according to the manufacturer's instructions. The gene regions of the large subunit of the nuclear ribosomal DNA (LSU), the internal transcribed spacers (ITS), the translation elongation factor (TEF1 $\alpha$ ) and RNA polymerase II subunit 2 (RPB2) were amplified using the primer pairs LROR/LR7 (Vilgalys \& Hester 1990), ITS5/ITS4 (White et al. 1990), 983F/2218R, fRPB2-5F/fRPB2-7cR (Liu et al. 1999) respectively. Primer sequences are available at the WASABI database at the AFTOL website (aftol.org). The PCR mixture contained $12.5 \mu \mathrm{l}$ of $2 \times$ Power Taq PCR MasterMix (a premix and ready to use solution, including 0.1 Units $/ \mu 1$ Taq DNA Polymerase, $500 \mu \mathrm{m}$ dNTP Mixture each (dATP, dCTP, dGTP, dTTP), $20 \mathrm{~mm}$ Tris- $\mathrm{HCl} \mathrm{pH} 8.3,100 \mathrm{MmKCl}, 3 \mathrm{mMMgCl}_{2}$, stabilizer and enhancer $), 1 \mu \mathrm{l}$ of each primer including forward primer and reverse primer $(10 \mu \mathrm{m}), 1 \mu$ template DNA extract and $9.5 \mu \mathrm{l}$ deionised water. The PCR thermal cycle program for ITS and LSU amplification was as follows: initial denaturation at $94{ }^{\circ} \mathrm{C}$ for $3 \mathrm{mins}$, followed by 40 cycles of denaturation at $95{ }^{\circ} \mathrm{C}$ for 30 seconds, annealing at $55^{\circ} \mathrm{C}$ for 50 seconds, elongation at $72{ }^{\circ} \mathrm{C}$ for 1 min. Regions of RPB2 and TEF1 $\alpha$ were amplified with initial denaturation at $95{ }^{\circ} \mathrm{C}$ for 5 mins, followed by 40 cycles of denaturation at $95{ }^{\circ} \mathrm{C}$ for $1 \mathrm{~min}$, annealing at $54{ }^{\circ} \mathrm{C}$ for 90 seconds, elongation at $72{ }^{\circ} \mathrm{C}$ for 90 seconds, and the final extension at $72{ }^{\circ} \mathrm{C}$ for 10 mins included for each condition of amplification. PCR products were then purified using mini-columns, purification resin and buffer according to the manufacturer's protocols (Amersham product code: 27-9602-01). The sequences were carried out at Beijing Tsingke Biological Engineering Technology and Services Co., Ltd (Beijing, P.R. China).

\section{Phylogenetic analysis and species recognition}

Sequence data for relevant strains were downloaded from GenBank following recent publications (Hyde et al. 2016b, Su et al. 2016, Xia et al. 2017, Yang et al. 2018). Consensus sequences were assembled with Sequencher 4.9 for Windows (Gene Codes Corp., Ann Arbor, Michigan) and aligned using MAFFT v.7.110 online program (http://mafft.cbrc.jp/alignment/server/) (Katoh \& Standley 2013) and manually adjusted via BioEdit 
v7.2.3 (Hall 1999). Phylogenetic analyses were performed by using PAUP v.4.0b10 (Swofford 2002) for maximum parsimony (MP) and MrBayes v.3.2.2 (Ronquist et al. 2012) for Bayesian analyses.

Phylogeny website tools "ALTER" (Glez-Peña et al. 2010) were used to transform the alignment fasta to Phylip file for RAxML analysis. Maximum likelihood (ML) analysis was performed at the CIPRES Science Gateway v.3.3 (http://www.phylo.org/portal2/; Miller et al. 2010) using RAxML v.8.2.8 as part of the "RAxML-HPC BlackBox" tool (Stamatakis 2006, Stamatakis et al. 2008). All free model parameters were estimated by RAxML with ML estimates of 25 per site rate categories. The final ML search was conducted using the GTRGAMMA + I model. The best scoring tree was selected with a final likelihood value of -22813.235538. RAxML bootstrap support values greater than $75 \%$ are given above at the branches (Fig. 1).

Bayesian analyses were performed by using PAUP v.4.0b10 (Swofford 2002) and MrBayes v3.2.2 (Ronquist et al. 2012). The model of evolution was estimated by using MrModeltest 2.2 (Nylander 2004). Posterior probabilities (Rannala \& Yang 1996) were performed by Markov Chain Monte Carlo Sampling (BMCMC) in MrBayes v. 3.0b4. Six simultaneous Markov Chains were run for 1 million generations and trees were sampled every 100th generation (resulting in 10000 trees). The first 2000 trees representing the burn-in phase of the analyses were discarded and the remaining 8000 (post burning) trees used for calculating posterior probabilities (PP) in the majority rule consensus tree.

All new sequence data generated in this study are deposited in GenBank (Table 1) and alignments are submitted in TreeBASE (www.treebase.org, submission number 22352). Resulting trees were viewed in Treeview (Page 1996). The terminals of the phylogenetic tree (Fig. 1) are labeled with species and the isolates/culture collection codes as provided in GenBank.

\section{Diversity analysis}

To compare the number of species for each locality, the number of all species will be calculated and then final numbers of species will be compared. Species diversity should be calculated using Shannon's diversity index $H^{\prime}$ (Shannon \& Weaver 1963):

$$
\mathrm{H}=-\sum_{i=1}^{s} P i \ln p i, p i=N i / \mathrm{N}
$$

$-N_{i}$ is individual number of $\mathrm{i}$ species

$-N$ is individual number of all species

$-P_{i}$ is the proportion of $i$ species

Then the Evenness $(E)$ is calculated using the formula: Evenness $(E)=H^{\prime} / \ln S$.

Simpson's Diversity Index (1-D) is used to compare with Shannon's diversity index and the formula is as follow: $\mathrm{D}=\Sigma \mathrm{n}(\mathrm{n}-1) / \mathrm{N}(\mathrm{N}-1)$ where $\mathrm{n}$ is the total number of organisms of a particular species and $\mathrm{N}$ is the total number of organisms of all species.

Index of similarity was calculated using Sorensen's formula to determine the similarity in species occurrences (Odum 1971). The similarity values range from 0 to 1 (1 meaning very similar, 0 indicating no similarity) by using the following formula:

$\left(S^{\prime}\right)=2 C /(A+B)$ where $S^{\prime}$ is the degree of similarity, $A$ and $B$ are the number of species at site $\mathrm{A}$ and site $\mathrm{B}$ respectively, $\mathrm{C}$ is the number of species common to both collections.

Although this is not an ecological study, we provide a standardized approach to study the lignicolous freshwater fungi in Asia. In this study, however, we deal with the fungal taxonomy and phylogeny as is essential to give names to all taxa before we can discuss their ecology. Ecological studies will be carried out in the future once we obtain enough data from different rivers and streams. 


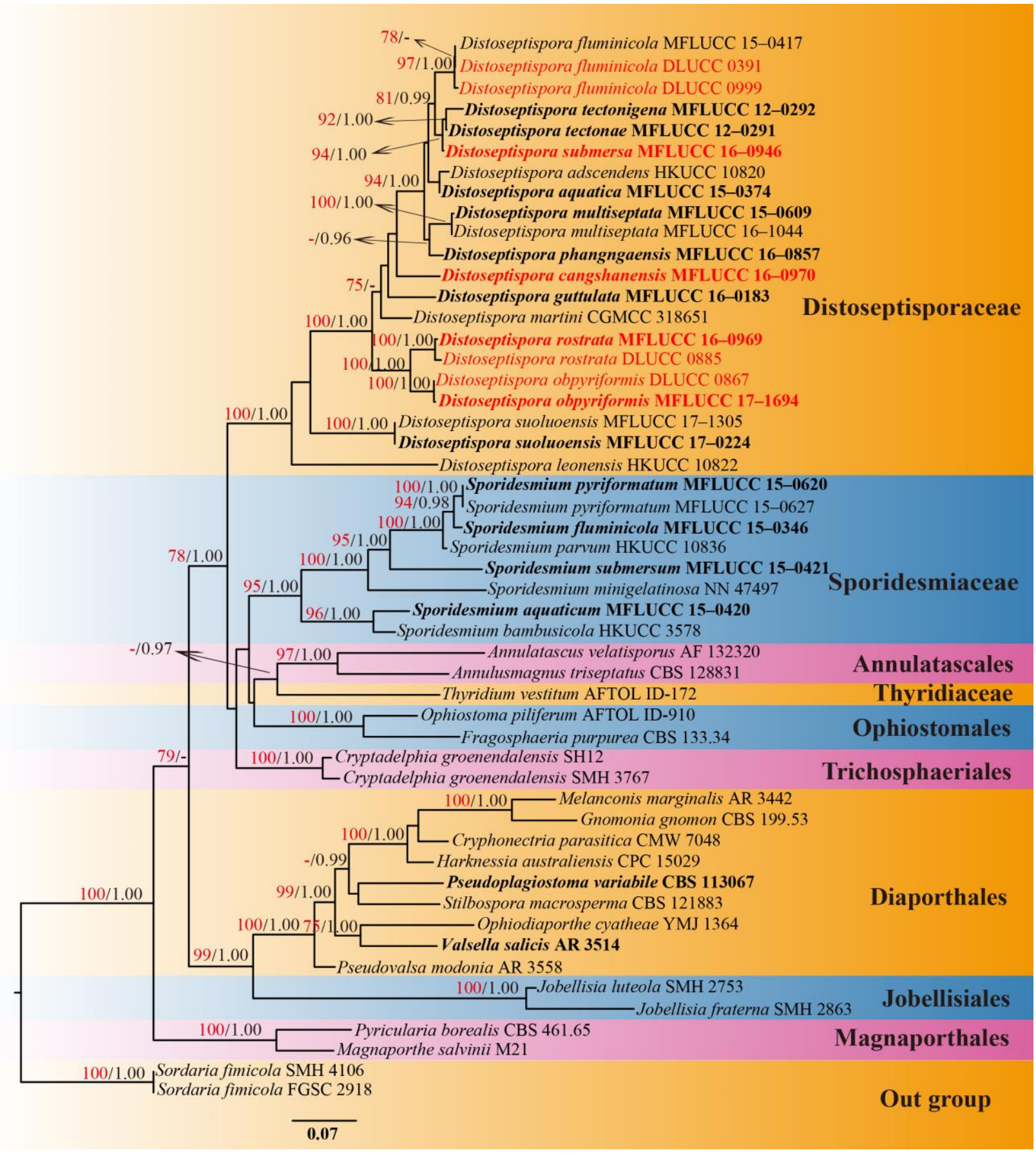

Figure 1 - Phylogram generated from maximum likelihood analysis (RAxML) based on combined ITS, LSU, RPB2 and TEF1 $\alpha$ sequence data from selected taxa in Sordariomycetes. Bootstrap support values for maximum likelihood (ML) greater than $75 \%$ and Bayesian posterior probabilities (PP) greater than 0.95 are given above the nodes. The tree is rooted to Sordaria fimicola (SMH 4106, FGSC 2918). Newly generated sequences are indicated in red and ex-type strains are in bold.

\section{Results}

\section{Phylogenetic analysis}

Eight isolates of hyphomycetous taxa were obtained from submerged decaying wood, and they were assigned to the family Distoseptisporaceae. Phylogenetic analysis of combined ITS, LSU, RPB2 and TEF1 $\alpha$ sequence data and morphological characters were used to assign the species and four novel species are introduced in this paper and compared with similar species (Table 2). 
Table 1 Isolates and sequences used in this study (newly generated sequences are indicated in bold, ex-type strains are indicated in $*$ after collection number).

\begin{tabular}{|c|c|c|c|c|c|c|}
\hline \multirow{2}{*}{ Species } & \multirow{2}{*}{\multicolumn{2}{|c|}{$\begin{array}{c}\text { Collection/Isolate } \\
\text { number }\end{array}$}} & \multicolumn{4}{|c|}{ GenBank accession number } \\
\hline & & & ITS & LSU & RPB2 & TEF1a \\
\hline Annulatascus velatisporus & HKUCC 3701 & & - & AF132320 & - & - \\
\hline Annulusmagnus triseptatus & CBS 128831 & & - & GQ996540 & JQ429258 & - \\
\hline Cryphonectria parasitica & CMW 7084 & & JN942325 & JN940858 & - & - \\
\hline $\begin{array}{l}\text { Cryptadelphia } \\
\text { groenendalensis }\end{array}$ & SH 12 & & - & EU528007 & - & - \\
\hline C. groenendalensis & SMH 3767 & & - & EU528001 & - & - \\
\hline Distoseptispora adscendens & HKUCC 10820 & & - & DQ408561 & DQ435092 & - \\
\hline D. aquatica & $\begin{array}{l}\text { MFLUCC } \\
\text { 0374* }\end{array}$ & $15-$ & MF077552 & KU376268 & - & - \\
\hline D. cangshanensis & $\begin{array}{l}\text { MFLUCC } \\
\text { 0970* }\end{array}$ & 16- & MG979754 & MG979761 & - & MG988419 \\
\hline D. fluminicola & $\begin{array}{l}\text { MFLUCC } \\
0417 *\end{array}$ & $15-$ & MF077553 & KU376270 & - & - \\
\hline D. fluminicola & DLUCC 0391 & & MG979755 & MG979762 & - & MG988420 \\
\hline D. fluminicola & DLUCC 0999 & & MG979756 & MG979763 & - & MG988421 \\
\hline D. guttulata & $\begin{array}{l}\text { MFLUCC } \\
0183^{*}\end{array}$ & $16-$ & MF077543 & MF077554 & - & MF135651 \\
\hline D. obpyriformis & $\begin{array}{l}\text { MFLUCC } \\
1694^{*}\end{array}$ & 17- & - & MG979764 & $\begin{array}{l}\text { MG98841 } \\
5\end{array}$ & MG988422 \\
\hline D. obpyriformis & DLUCC 0867 & & MG979757 & MG979765 & $\begin{array}{c}\text { MG98841 } \\
6\end{array}$ & MG988423 \\
\hline D. leonensisi & HKUCC 10822 & & - & DQ408566 & DQ435089 & - \\
\hline D. martini & CGMCC 31865 & & KU999975 & KX033566 & - & - \\
\hline D. multiseptata & MFLUCC $16-1$ & 044 & MF077544 & MF077555 & MF135644 & MF135652 \\
\hline D. multiseptata & $\begin{array}{l}\text { MFLUCC } \\
0609^{*}\end{array}$ & $15-$ & KX710145 & KX710140 & - & MF135659 \\
\hline D. phangngaensis & $\begin{array}{l}\text { MFLUCC } \\
0857^{*}\end{array}$ & $16-$ & MF077545 & MF077556 & - & MF135653 \\
\hline D. rostrata & $\begin{array}{l}\text { MFLUCC } \\
0969^{*}\end{array}$ & 16- & MG979758 & MG979766 & $\begin{array}{c}\text { MG98841 } \\
7\end{array}$ & MG988424 \\
\hline D. rostrata & DLUCC 0885 & & MG979759 & MG979767 & - & MG988425 \\
\hline D. submersa & $\begin{array}{l}\text { MFLUCC } \\
\text { 0946* }^{*}\end{array}$ & 16- & MG979760 & MG979768 & $\begin{array}{c}\text { MG98841 } \\
8\end{array}$ & MG988426 \\
\hline D. suoluoensis & $\begin{array}{l}\text { MFLUCC } \\
\text { 0224* }\end{array}$ & $17-$ & MF077546 & MF077557 & - & MF135654 \\
\hline D. suoluoensis & MFLUCC 17-1? & 305 & MF077547 & MF077558 & - & - \\
\hline D. tectonae & $\begin{array}{l}\text { MFLUCC } \\
\text { 0291* }\end{array}$ & $12-$ & KX751711 & KX751713 & KX751708 & KX751710 \\
\hline D. tectonigena & $\begin{array}{l}\text { MFLUCC } \\
0292^{*}\end{array}$ & $12-$ & KX751712 & KX751714 & KX751709 & - \\
\hline Fragosphaeria purpurea & CBS 133.34 & & AB278192 & AB189154 & - & - \\
\hline Gnomonia gnomon & CBS 199.53 & & AY818956 & AF408361 & DQ470922 & DQ471094 \\
\hline Harknessia australiensis & СРC 15029 & & JQ706085 & JQ706211 & - & - \\
\hline Jobellisia fraternal & SMH 2863 & & - & AY346285 & - & - \\
\hline J. luteola & SMH 2753 & & - & AY346286 & - & - \\
\hline Magnaporthe salvinii & M 21 & & - & JF414887 & - & JF710406 \\
\hline Melanconis marginalis & AR 3442 & & - & AF408373 & EU219301 & EU221991 \\
\hline Ophiodiaporthe cyatheae & YMJ 1364 & & JX570889 & JX570891 & JX570893 & - \\
\hline $\begin{array}{l}\text { Pseudoplagiostoma } \\
\text { variabile }\end{array}$ & CBS $113067^{*}$ & & GU973536 & GU973611 & - & - \\
\hline Pseudovalsa modonia & AR 3558 & & - & EU683073 & - & - \\
\hline
\end{tabular}


Table 1 Continued.

\begin{tabular}{|c|c|c|c|c|c|}
\hline \multirow{2}{*}{ Species } & \multirow{2}{*}{$\begin{array}{c}\text { Collection/Isolate } \\
\text { number }\end{array}$} & \multicolumn{4}{|c|}{ GenBank accession number } \\
\hline & & ITS & LSU & RPB2 & TEF1a \\
\hline Pyricularia borealis & CBS 461.65 & KM009162 & KM009150 & - & KM009198 \\
\hline Sordaria fimicola & SMH 4106 & - & AY780079 & AY780194 & - \\
\hline Sordaria fimicola & FGSC 2918 & - & FR774289 & - & FR774388 \\
\hline Sporidesmium aquaticum & $\begin{array}{l}\text { MFLUCC } \\
0420^{*}\end{array}$ & - & KU376273 & - & - \\
\hline S. bambusicola & HKUCC 3578 & - & DQ408562 & - & - \\
\hline S. fluminicola & $\begin{array}{l}\text { MFLUCC } \\
0346^{*}\end{array}$ & - & KU376271 & - & - \\
\hline S. minigelatinosa & NN 47497 & - & DQ408567 & DQ435090 & - \\
\hline S. parvum & HKUCC 10836 & - & DQ408558 & - & - \\
\hline S. pyriformatum & $\begin{array}{l}\text { MFLUCC } \\
0620^{*}\end{array}$ & KX710146 & KX710141 & MF135649 & MF135662 \\
\hline S. pyriformatum & MFLUCC 15-0627 & KX710148 & KX710143 & MF135650 & MF135663 \\
\hline Stilbospora macrosperma & CBS 121883 & JX517290 & JX517299 & - & - \\
\hline Valsa ambiens & AR 3514 & - & EU255210 & EU219346 & EU222018 \\
\hline
\end{tabular}

Table 2 Habitat and morphological comparison among species of Distoseptispora.

\begin{tabular}{|c|c|c|c|c|}
\hline Species & Habitats & Conidiophores & Conidia & References \\
\hline $\begin{array}{l}\text { Distoseptispora } \\
\text { aquatica }\end{array}$ & Freshwater & $\begin{array}{l}29-41 \times 7-9 \mu \mathrm{m}, \text { tapering } \\
\text { distally, robust at base, dark } \\
\text { brown, 1-3-septate }\end{array}$ & $\begin{array}{l}110-157 \times 13.5-16.5 \mu \mathrm{m}, \\
\text { obclavate, elongated, dark } \\
\text { brown with bluish green to } \\
\text { malachite green tinge, } 15-28- \\
\text { distoseptate }\end{array}$ & Su et al. 2016 \\
\hline D. cangshanensis & Freshwater & $\begin{array}{l}44-68 \times 4-8 \mu \mathrm{m} \text {, cylindrical, } \\
\text { mid olivaceous to brown, } 1-5- \\
\text { septate }\end{array}$ & $\begin{array}{l}58-166(-287) \times 10-14 \mu \mathrm{m}, \\
\text { obclavate or lanceolate, } \\
\text { olivaceous or brown, multi- } \\
\text { distoseptate }\end{array}$ & This study \\
\hline D. fluminicola & Freshwater & 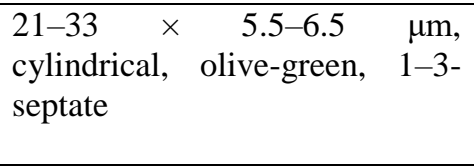 & $\begin{array}{l}125-250 \times 13-15 \mu \mathrm{m} \text {, oblong, } \\
\text { obclavate or cylindrical, } \\
\text { brown with green tinge, } 17-34- \\
\text { distoseptate }\end{array}$ & Su et al. 2016 \\
\hline D. guttulata & Freshwater & $\begin{array}{l}55-90(-145) \times 3.5-5.5 \mu \mathrm{m}, \\
\text { cylindrical, mid or dark brown, } \\
3-4(-10) \text {-septate }\end{array}$ & $\begin{array}{l}75-130(-165) \times 7-11 \mu \mathrm{m}, \\
\text { obclavate or lanceolate, } \\
\text { rostrate, mid to dark brown or } \\
\text { olivaceous, } \\
\text { euseptate }\end{array}$ & $\begin{array}{l}\text { Yang et al. } \\
2018\end{array}$ \\
\hline D. obpyriformis & Freshwater & $\begin{array}{l}97-119 \times 5-7 \mu \mathrm{m}, \text { cylindrical, } \\
\text { pale to dark brown, 5-6(-10)- } \\
\text { septate }\end{array}$ & $\begin{array}{l}\text { 53-71 } \times \text { 12-16 } \mu \mathrm{m} \text {, } \\
\text { obpyriform, olivaceous to pale } \\
\text { or dark brown, 9-11- } \\
\text { distoseptate }\end{array}$ & This study \\
\hline D. martinii & Terrestrial & $\begin{array}{l}50-110 \times 3.5-4.5 \quad \mu \mathrm{m}, \\
\text { cylindrical, dark brown the } \\
\text { most part, paler towards the } \\
\text { apex, 4-9-septate }\end{array}$ & $\begin{array}{l}15-20 \times 11-16 \mu \mathrm{m} \text {, transversal } \\
\text { ellipsoid, oblate or subglobose, } \\
\text { muriform, pale brown to brown }\end{array}$ & $\begin{array}{l}\text { Xia et al. } \\
2017\end{array}$ \\
\hline D. multiseptata & Freshwater & $\begin{array}{l}23-65 \times 4.5-8.5 \mu \mathrm{m} \text {, slightly } \\
\text { tapering distally, truncate at the } \\
\text { apex, brown, } 2-3 \text {-septate }\end{array}$ & 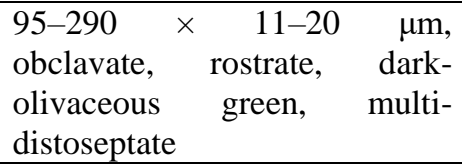 & $\begin{array}{l}\text { Hyde et al. } \\
2016 b\end{array}$ \\
\hline D. phangngaensis & Freshwater & $\begin{array}{l}18-30(-40) \times 4.3-6.5 \mu \mathrm{m}, \\
\text { tapering distally, brown, } 2-3- \\
\text { septate }\end{array}$ & $\begin{array}{l}165-350 \times 14-19 \mu \mathrm{m}, \\
\text { elongate, obclavate, rostrate, } \\
\text { dark olivaceous to mid or dark } \\
\text { brown, multi-distoseptate }\end{array}$ & $\begin{array}{l}\text { Yang et al. } \\
2018\end{array}$ \\
\hline
\end{tabular}


Table 2 Continued.

\begin{tabular}{|c|c|c|c|c|}
\hline Species & Habitats & Conidiophores & Conidia & References \\
\hline D. rostrata & Freshwater & $\begin{array}{l}82-126 \times 5-7 \mu \mathrm{m} \text {, cylindrical, } \\
\text { pale brown to brown, 4-7- } \\
\text { septate }\end{array}$ & $\begin{array}{l}115-155 \times 9-11 \mu \mathrm{m}, \text { obclavate } \\
\text { or lanceolate, rostrate, } \\
\text { olivaceous to pale brown, }(15- \\
\text { )18-23-distoseptate }\end{array}$ & This study \\
\hline D. submersa & Freshwater & $\begin{array}{l}55-73 \times 7-9 \mu \mathrm{m} \text {, cylindrical, } \\
\text { brown to dark brown, 4-5- } \\
\text { septate }\end{array}$ & 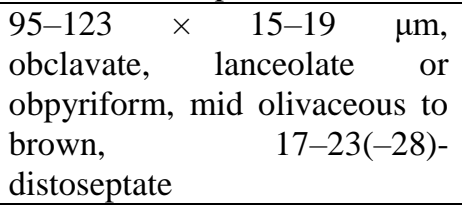 & This study \\
\hline D. suoluoensis & Freshwater & $\begin{array}{l}80-250 \times 4.5-5.8 \quad \mu \mathrm{m}, \\
\text { cylindrical, dark brown, paler at } \\
\text { the apical part, septate }\end{array}$ & $\begin{array}{l}(65-) 80-125(-145) \times 8-13 \\
\mu \mathrm{m}, \text { narrowly obclavate or } \\
\text { obspathulate, yellow brown or } \\
\text { dark olivaceous, verrucose, } 8- \\
\text { 10-euseptate }\end{array}$ & $\begin{array}{l}\text { Yang et al. } \\
2018\end{array}$ \\
\hline D. tectonae & Terrestrial & $\begin{array}{l}\text { Up to } 40 \times 4-6 \mu \mathrm{m} \text {, cylindrical, } \\
\text { pale brown to dark brown, } 2-4- \\
\text { septate }\end{array}$ & $\begin{array}{l}(90-) 130-140(-170) \times 13-14 \\
\mu \mathrm{m}, \quad \text { cylindric-obclavate, } \\
\text { elongate, dark reddish brown, } \\
\text { verrucose, } 20-28-\text { distoseptate }\end{array}$ & $\begin{array}{l}\text { Hyde et al. } \\
2016 b\end{array}$ \\
\hline D. tectonigena & Terrestrial & $\begin{array}{l}\text { Up to } 110 \times 5-11 \mu \mathrm{m}, \\
\text { cylindrical, pale brown to dark } \\
\text { brown, septate }\end{array}$ & $\begin{array}{l}148-225(-360) \times 11-12 \mu \mathrm{m}, \\
\text { cylindric-obclavate, elongate, } \\
\text { dark reddish brown, 20-46- } \\
\text { distoseptate }\end{array}$ & $\begin{array}{l}\text { Hyde et al. } \\
2016 b\end{array}$ \\
\hline
\end{tabular}

A combined dataset of 3069 characters (ITS, LSU, RPB2 and TEF1 $\alpha$ ) including gaps with 51 taxa analyzed using RAxML and Bayesian analyses resulted in trees which were topologically congruent with respect to the position of the new taxa investigated. Fig. 1 represents the phylogram generated using ML analysis (value of likelihood: -22813.235538). Twenty-one taxa of Distoseptisporaceae including four new species formed a monotypic clade among the selected families or orders of Sordariomycetes with strong support (100\% ML and 1.00 PP). The newly collected Distoseptispora fluminicola isolates cluster with its ex-type strain with high support (97\% ML and $1.00 \mathrm{PP}$ ). A strain of the new species Distoseptispora submersa clustered with D. tectonigena and D. tectonae in a well-supported monophyletic clade (94\% ML and 1.00 PP). The isolate of $D$. cangshanensis forms a distinct clade among the species of Distoseptispora, but is weakly supported. Distoseptispora rostrata clusters with $D$. obpyriformis in a strongly-supported monophyletic clade (100\% ML and $1.00 \mathrm{PP}$ ) between D. suoluoensis and D. martini.

\section{Taxonomy}

Distoseptispora cangshanensis Z.L. Luo, K.D. Hyde \& H.Y. Su, sp. nov.

Fig. 2

Index Fungorum number: IF554289; Facesoffungi number: FoF04193

Etymology - Referring to the collection site from Cangshan Mountain in China.

Holotype - MFLU 18-0474

Saprobic on decaying, submerged wood in freshwater habitats. Sexual morph: Undetermined. Asexual morph: Colonies effuse, olivaceous or brown, hairy or velvety. Mycelium mostly immersed, consisting of branched, septate, smooth, subhyaline to pale brown hyphae. Conidiophores macronematous, mononematous, mid-olivaceous to brown, solitary, 1-5-septate, erect, straight or flexuous, unbranched, smooth, cylindrical, 44-68 $\mu \mathrm{m}$ long $(\bar{x}=56 \mu \mathrm{m}, \mathrm{SD}=12, \mathrm{n}$ $=15), 4-8 \mu \mathrm{m}$ wide $(\bar{x}=6 \mu \mathrm{m}, \mathrm{SD}=2, \mathrm{n}=15)$, truncate at the apex. Conidiogenous cells monoblastic, integrated, terminal, determinate, subhyaline to pale brown, cylindrical. Conidia acrogenous, solitary, obclavate or lanceolate, rostrate, straight or slightly curved, multi-distoseptate, olivaceous or brown, tapering towards the rounded apex, truncate at the base, 58-166(-287) $\mu \mathrm{m}$ long $(\bar{x}=112 \mu \mathrm{m}, \mathrm{SD}=54, \mathrm{n}=30), 10-14 \mu \mathrm{m}$ wide $(\bar{x}=12 \mu \mathrm{m}, \mathrm{SD}=2, \mathrm{n}=30)$ at the broadest 
part, 4-6 $\mu \mathrm{m}$ wide $(\bar{x}=5 \mu \mathrm{m}, \mathrm{SD}=1, \mathrm{n}=30)$ at the apex, slightly constricted at septa, smoothwalled.

Material examined - CHINA, Yunnan Province, saprobic on decaying wood submerged in a stream in Cangshan Mountain, May 2014, Q. Dai, S-220 (MFLU 18-0474, holotype), ex-type living culture MFLUCC 16-0970.

Notes - Distoseptispora cangshanensis is mostly similar to D. rostrata in having cylindrical, septate conidiophores, and the same shape, coloured, multi-distoseptate and similar sized conidia. However, they can be distinguished by DNA sequence data, that have 13bp (base pair), 46bp and 56bp nucleotide differences in LSU, ITS and TEF1 $\alpha$ respectively, when compared to $D$. cangshanensis and D. rostrata by using single gene region sequence data (Jeewon \& Hyde 2016). Distoseptispora cangshanensis also shares similar characters with D. guttulata in having cylindrical, septate conidiophores and obclavate or lanceolate, olivaceous or brown conidia. However, $D$. cangshanensis differs from $D$. guttulata by its distoseptate conidia, while $D$. guttulata has euseptate conidia and $D$. cangshanensis has shorter conidiophore (44-68 vs 55-145 $\mu \mathrm{m}$ ) (Yang et al. 2018).

Distoseptispora obpyriformis Z.L. Luo \& H.Y. Su, sp. nov.

Fig. 3

Index Fungorum number: IF 554290; Facesoffungi number: FoF04194

Etymology - Referring to the obpyriform conidia of this fungus.

Holotype - MFLU 18-0476

Saprobic on decaying, submerged wood in freshwater habitats. Sexual morph: undetermined. Asexual morph: Colonies effuse, olivaceous or dark brown, hairy, velvety. Mycelium mostly immersed, consisting of branched, septate, smooth, subhyaline to pale brown hyphae. Conidiophores macronematous, mononematous, pale to dark brown, solitary, 5-6(-10)-septate, erect, straight or slightly flexuous, unbranched, smooth, cylindrical, 97-119 $\mu \mathrm{m}$ long $(\bar{x}=108 \mu \mathrm{m}$, $\mathrm{SD}=11, \mathrm{n}=20), 5-7 \mu \mathrm{m}$ wide $(\bar{x}=6 \mu \mathrm{m}, \mathrm{SD}=1, \mathrm{n}=20)$, rounded at the apex. Conidiogenous cells monoblastic, integrated, terminal, determinate, pale to dark brown, cylindrical. Conidia acrogenous, solitary, obpyriform, 9-11-distoseptate, thick-walled, olivaceous to pale or dark brown, tapering towards the rounded apex, slightly curved, truncate at the base, guttulate, 53-71 $\mu \mathrm{m}$ long $(\bar{x}=62 \mu \mathrm{m}, \mathrm{SD}=9, \mathrm{n}=25), 12-16 \mu \mathrm{m}$ wide $(\bar{x}=14 \mu \mathrm{m}, \mathrm{SD}=2, \mathrm{n}=25)$, smooth-walled.

Material examined - CHINA, Yunnan Province, saprobic on decaying wood submerged in Nujiang River, May 2015, Z.L. Luo, S-769 (MFLU 18-0476, holotype), ex-type living culture MFLUCC 17-1694; October 2016, Z.L. Luo, S-867 (MFLU 18-0477, paratype) living culture DLUCC 0867.

Notes - Two specimens of Distoseptispora obpyriformis were collected from Nujiang River but in different collecting seasons and sites. Distoseptispora obpyriformis shares similar morphological characters with $D$. rostrata in the shape, colour and size of its conidiophores, however, D. obpyriformis differs from $D$. rostrata in having obpyriform, shorter conidia (53-71 vs $115-155 \mu \mathrm{m}$ ) and they are also phylogenetically distinct (Fig. 1). Additionally, with the exception of D. martinii, the short conidia of D. obpyriformis are also different from the longer conidia of other Distoseptispora species (Table 2).

Distoseptispora rostrata Z.L. Luo, K.D. Hyde \& H.Y. Su, sp. nov.

Fig. 4

Index Fungorum number: IF 554291; Facesoffungi number: FoF04195

Etymology - Referring to the rostrate conidia of this fungus.

Holotype - MFLU 18-0479

Saprobic on decaying, submerged wood in freshwater habitats. Sexual morph: undetermined. Asexual morph: Colonies effuse, olivaceous or brown, hairy or velvety. Mycelium mostly immersed, consisting of branched, septate, smooth, subhyaline to pale brown hyphae. Conidiophores macronematous, mononematous, pale brown to brown, solitary, 4-7-septate, erect, straight or slightly flexuous, unbranched, smooth, cylindrical, $82-126 \mu \mathrm{m}$ long $(\bar{x}=104 \mu \mathrm{m}, \mathrm{SD}=$ $22, \mathrm{n}=15), 5-7 \mu \mathrm{m}$ wide $(\bar{x}=6 \mu \mathrm{m}, \mathrm{SD}=1, \mathrm{n}=15)$, rounded at the apex. Conidiogenous cells monoblastic, integrated, terminal, determinate, pale to dark brown, cylindrical, sometimes with 
percurrent proliferation. Conidia acrogenous, solitary, obclavate or lanceolate, rostrate, straight or slightly curved, (15-)18-23-distoseptate, olivaceous to pale brown, slightly tapering towards the rounded apex, truncate at the base, $115-155 \mu \mathrm{m}$ long $(\bar{x}=135 \mu \mathrm{m}, \mathrm{SD}=20, \mathrm{n}=30), 9-11 \mu \mathrm{m}$ wide $(\bar{x}=10 \mu \mathrm{m}, \mathrm{SD}=1, \mathrm{n}=30)$, smooth-walled.

Material examined - CHINA, Yunnan Province, saprobic on decaying wood submerged in Nujiang River, May 2015, X.J. Su, S-351 (MFLU 18-0479, holotype, HKAS 92781, isotype), extype living culture MFLUCC 16-0969; October 2016, Z.L. Luo, S-885 (MFLU 18-0475, paratype) living culture DLUCC 0885.

Notes - Distoseptispora rostrata resembles D. guttulata in having cylindrical, pale brown to brown, septate conidiophores and obclavate or lanceolate, rostrate, olivaceous conidia. However, $D$. rostrata can be distinguished from $D$. guttulata by its (15-)18-23-distoseptate conidia, while $D$. guttulata has 11-14(-20)-euseptate conidia. The multi-gene phylogenetic analyses also showed that they are different species (Fig. 1).

Distoseptispora submersa Z.L. Luo, K.D. Hyde \& H.Y. Su, sp. nov.

Fig. 5

Index Fungorum number: IF554292; Facesoffungi number: FoF04196

Etymology - Referring to the submerged habitats of the fungus

Holotype - MFLU 18-0478

Saprobic on decaying, submerged wood in freshwater habitats. Sexual morph: undetermined. Asexual morph: Colonies effuse, olivaceous or black, hairy or velvety. Mycelium mostly immersed, consisting of branched, septate, smooth, hyaline to pale brown hyphae. Conidiophores macronematous, mononematous, brown to dark brown, solitary, 4-5-septate, erect, straight or flexuous, unbranched, smooth, cylindrical, rarely percurrently proliferating, 55-73 $\mu \mathrm{m}$ long $(\bar{x}=64$ $\mu \mathrm{m}, \mathrm{SD}=9, \mathrm{n}=15), 7-9 \mu \mathrm{m}$ wide $(\bar{x}=8 \mu \mathrm{m}, \mathrm{SD}=1, \mathrm{n}=15)$, truncate at the apex. Conidiogenous cells monoblastic, integrated, terminal, determinate, brown, cylindrical. Conidia acrogenous, solitary, obclavate, lanceolate, rostrate, straight or slightly curved, 17-23(-28)-distoseptate, mid olivaceous to brown, tapering towards the rounded apex, truncate at the base, $95-123 \mu \mathrm{m}$ long $(\bar{x}=$ $109 \mu \mathrm{m}, \mathrm{SD}=14, \mathrm{n}=20), 15-19 \mu \mathrm{m}$ wide $(\bar{x}=17 \mu \mathrm{m}, \mathrm{SD}=2, \mathrm{n}=20)$, smooth-walled.

Material examined - CHINA, Yunnan Province, saprobic on decaying wood submerged in Nujiang River, May 2015, Q. Dai, S-301 (MFLU 18-0478, holotype, HKAS 92806, isotype), extype living culture MFLUCC 16-0946.

Notes - Distoseptispora submersa agrees with the generic concept of Distoseptispora in having macronematous, olivaceous to brown, cylindrical conidiophores, monoblastic, integrated, determinate, terminal conidiogenous cells and obclavate, lanceolate, rostrate, distoseptate conidia (Yang et al. 2018). Distoseptispora submersa is phylogenetically close to D. tectonae, but D. submersa have larger conidiophores $(55-73 \times 7-9 \mu \mathrm{m}$ vs up to $40 \times 4-6 \mu \mathrm{m})$ and shorter conidia (95-123 vs 130-140 $\mu \mathrm{m})$ (Table 2).

\section{Discussion}

Sporidesmium-like taxa are commonly collected from terrestrial habitats (Wu \& Zhuang 2007), but they have frequently been recorded from submerged decaying wood in freshwater (Hyde \& Goh 1998a, Ho et al. 2001, Cai et al. 2003, Hyde et al. 2016b, Su et al. 2016, Yang et al. 2018). Sporidesmium and its related genera are an interesting group as they share similar characters in having holoblastic, septate conidia and monoblastic, determinate or percurrent conidiogenous cells, and are difficult to classify based on morphology alone (Shenoy et al. 2006, Su et al. 2016, Yang et al. 2018). In this study, we collected five sporidesmium-like taxa from rivers and streams in northwestern Yunnan, China. Phylogenetic analyses show that eight hyphomycetous strains are positioned in Distoseptisporaceae in a robust clade. Four new Distoseptispora species are introduced in this paper based on morphology and molecular sequence data. 

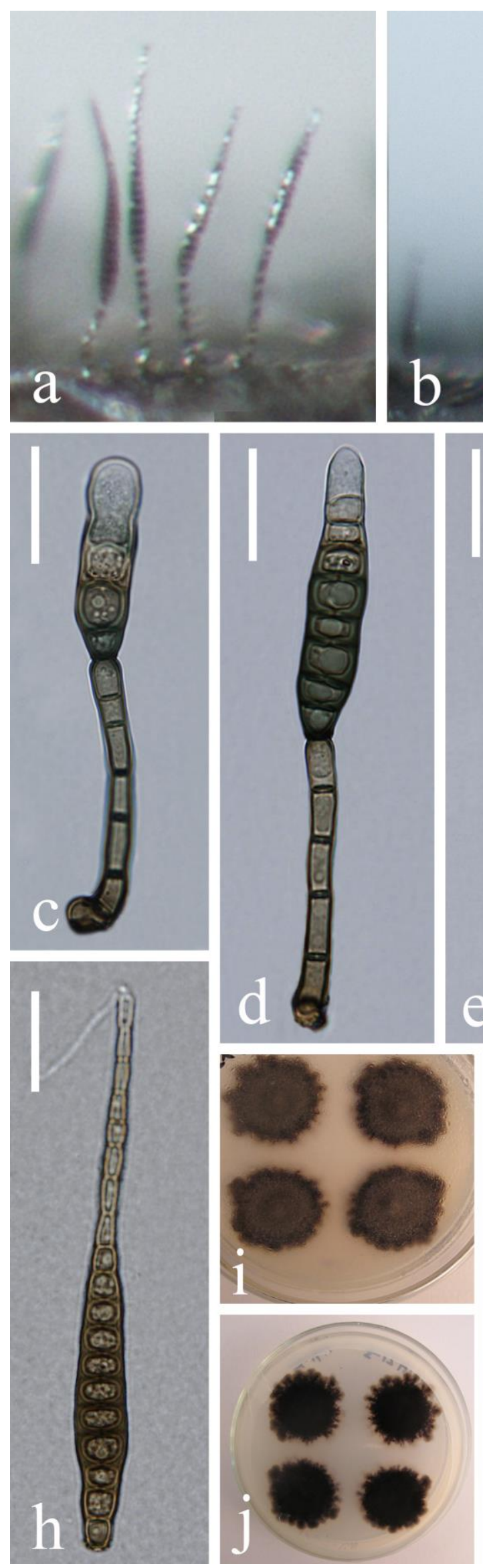

Figure 2 - Distoseptispora cangshanensis (MFLU 18-0474, holotype). a, b Colonies on substrate. c-g Conidiophores with conidia. $\mathrm{k}-\mathrm{o}$ Conidia. h Germinating conidium. i, j Culture on PDA (j from below). Scale bars: $\mathrm{f}, \mathrm{g}=60 \mu \mathrm{m}, \mathrm{c}-\mathrm{e}, \mathrm{h}, \mathrm{k}-\mathrm{o}=30 \mu \mathrm{m}$.
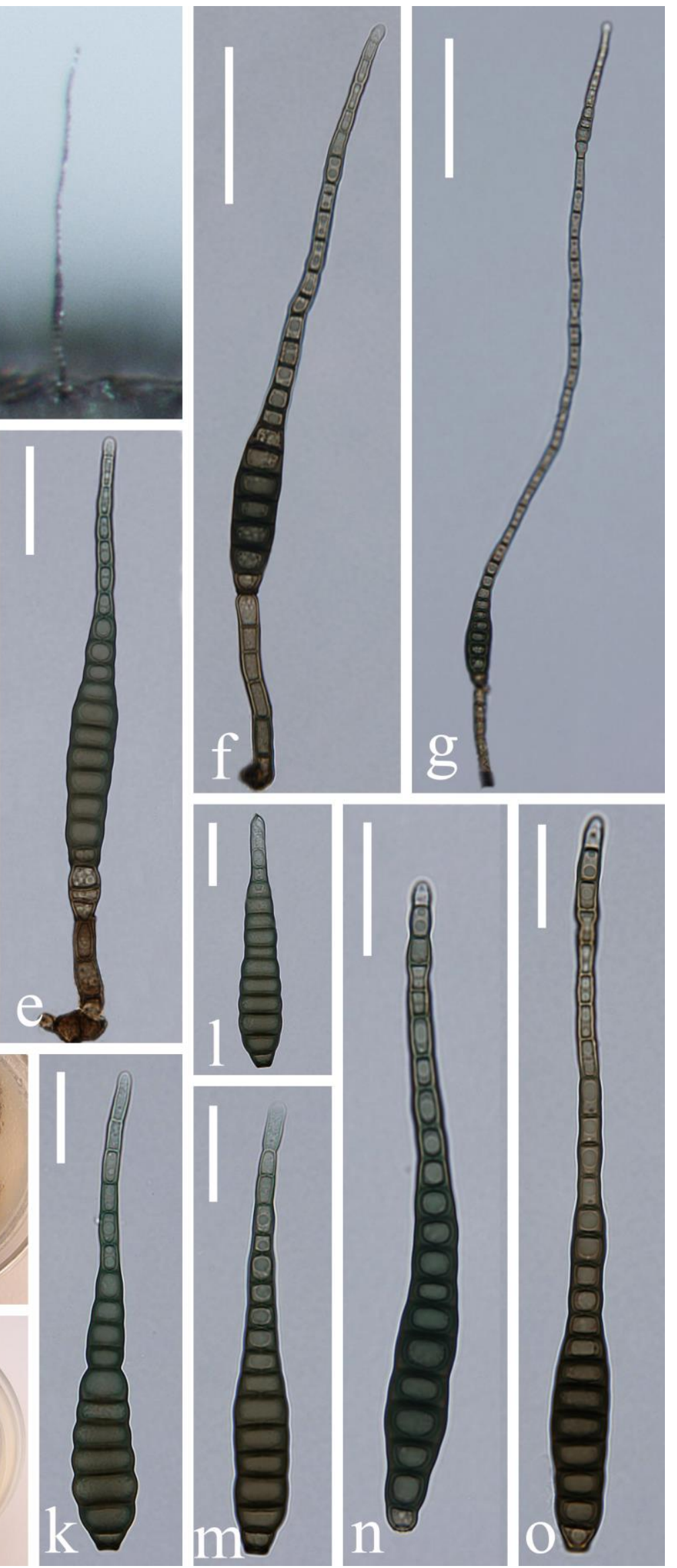

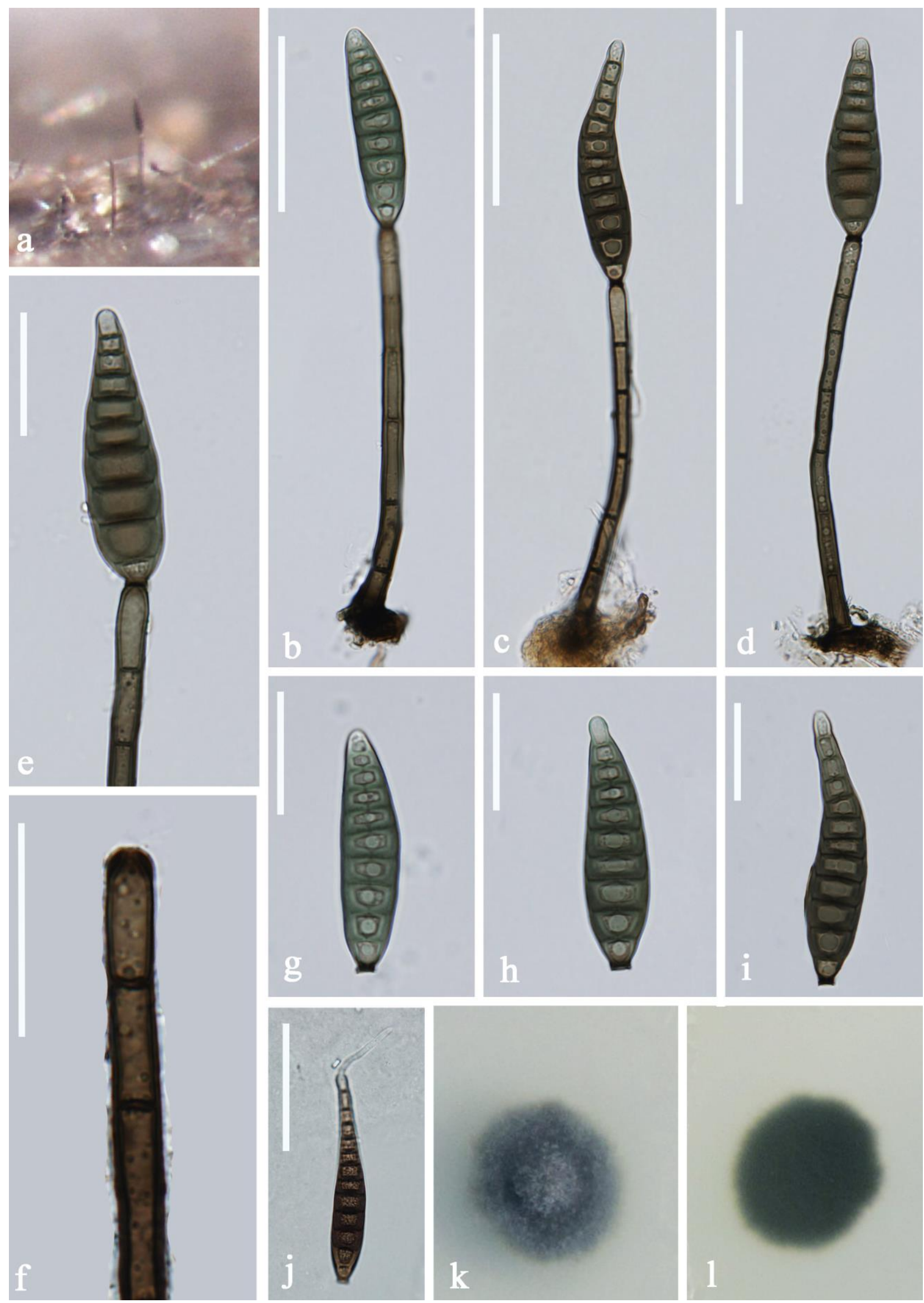

Figure 3 - Distoseptispora obpyriformis (MFLU 18-0476, holotype). a Colonies on substrate. $\mathrm{b}-\mathrm{d}$ Conidiophores and conidia. e, f Conidiogenesis. g-i Conidia. j Germinating conidium. $k, 1$ Culture on PDA after 21 days (1 from below). Scale bars: $b-d=50 \mu \mathrm{m}, e-j=30 \mu \mathrm{m}$. 

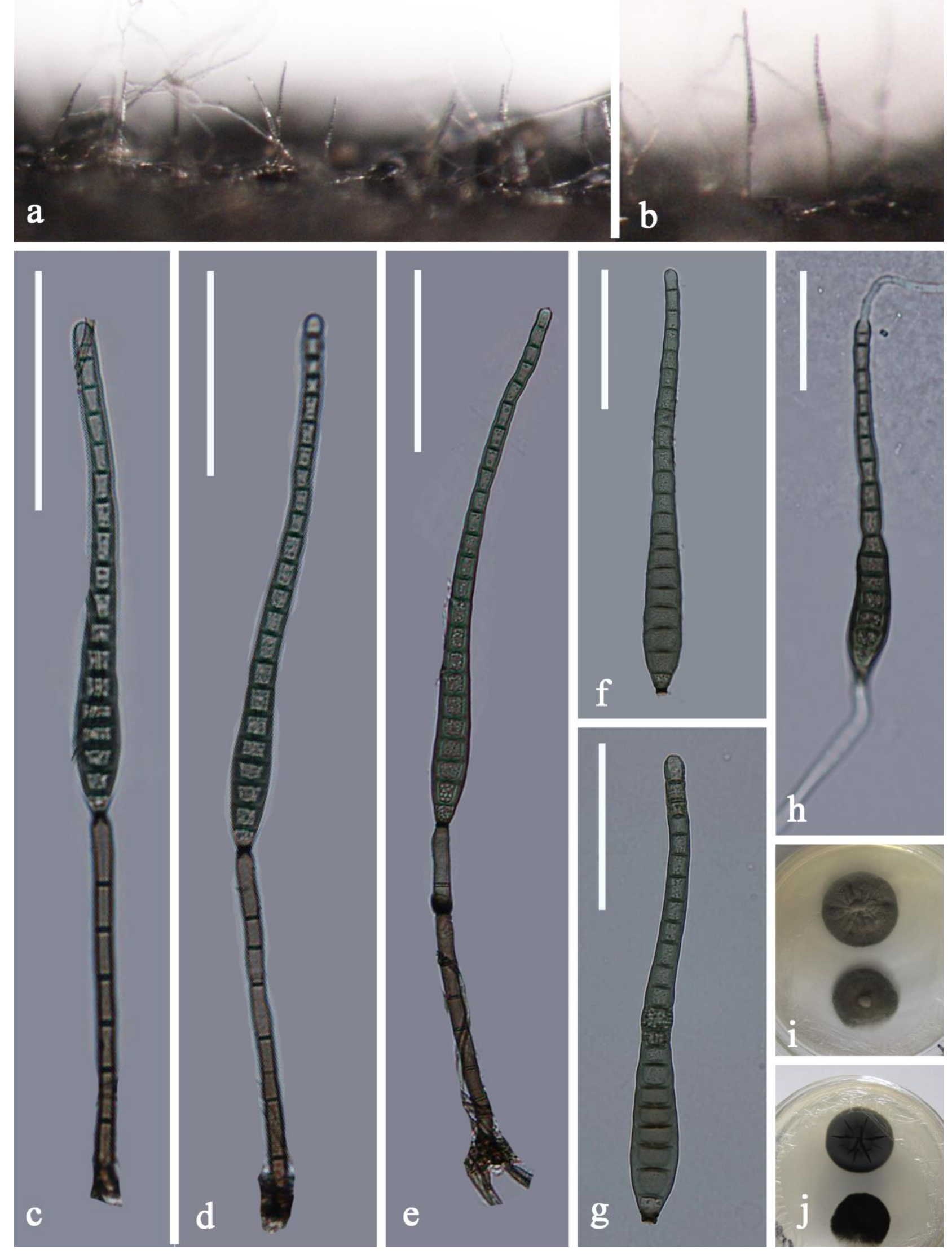

Figure 4 - Distoseptispora rostrata (MFLU 18-0479, holotype) a, b Colonies on substrate. c-e Conidiophores and conidia. f, g Conidia. h Germinating conidium. i, j Culture on PDA after 21 days ( 1 from below). Scale bars: $\mathrm{c}-\mathrm{e}=70 \mu \mathrm{m}, \mathrm{f}-\mathrm{h}=50 \mu \mathrm{m}$. 

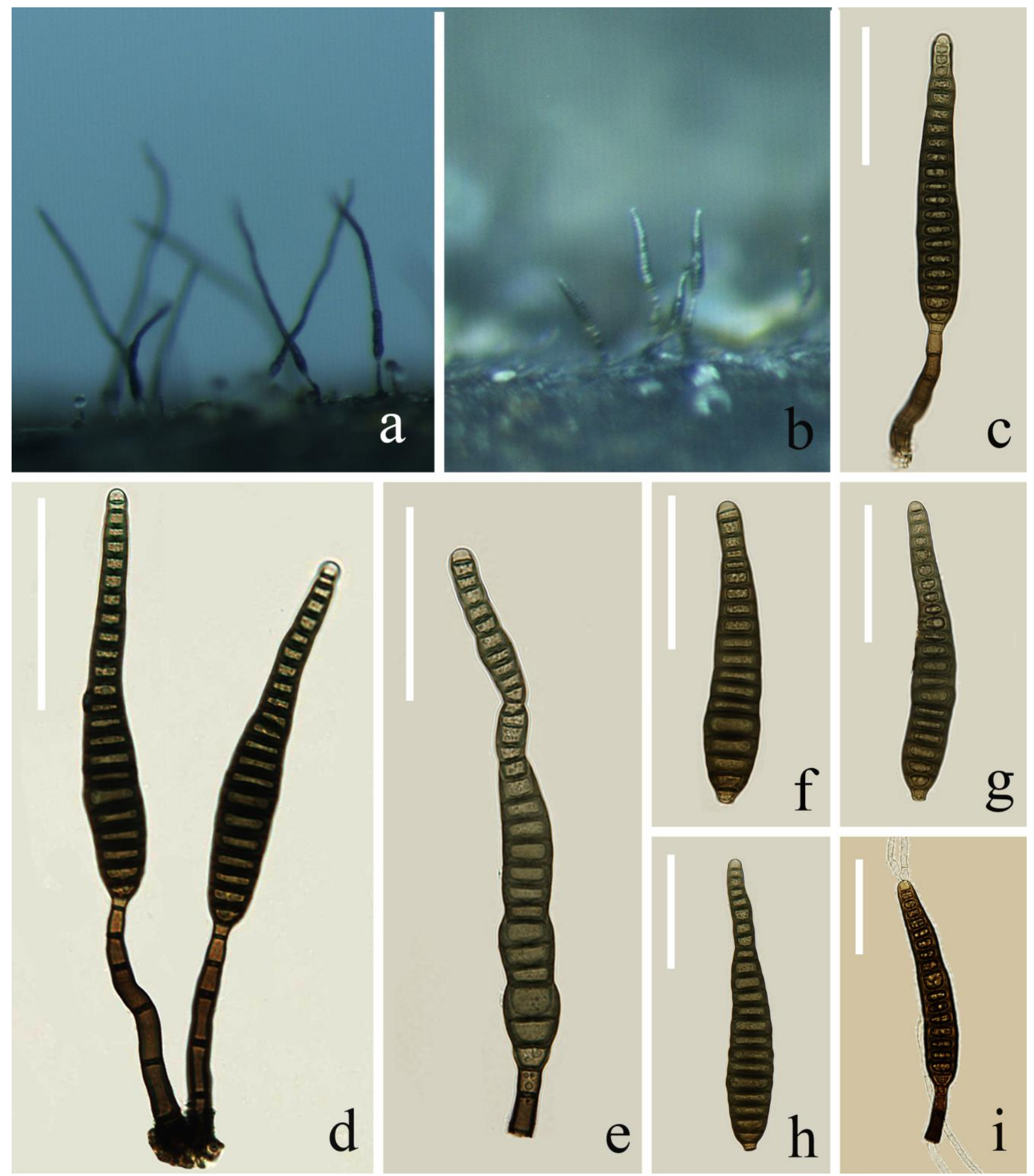

Figure 5 - Distoseptispora submersa (MFLU 18-0478, holotype) a, b Colonies on substrate. $\mathrm{c}, \mathrm{d}$ Conidiophores and conidia. e Conidiogenesis with conidia. $\mathrm{f}-\mathrm{h}$ Conidia. i Germinating conidium. Scale bars: $\mathrm{c}-\mathrm{i}=50 \mu \mathrm{m}$.

Distoseptispora is an asexual genus and there are presently no reports on the sexual morph of this genus. There are nine species presently accepted in Distoseptispora, with five species reported from Thailand (Hyde et al. 2016b, Yang et al. 2018) and four species from southwestern China (Su et al. 2016, Yang et al. 2018). All Distoseptispora species are saprobic and isolated from the decaying wood in terrestrial or aquatic habitats in tropical or subtropical regions. Xia et al. (2017) transferred Acrodictys martinii to the genus Distoseptispora as D. martinii based on their phylogenetic analysis, but this species is easily distinguished from other species in Distoseptispora 
(Distoseptisporaceae) by its transversal ellipsoid, oblate or subglobose, muriform conidia. Most Acrodictys-like species belong to Acrodictyaceae, Junewangiaceae or Savoryellaceae (Xia et al. 2017).

\section{Acknowledgments}

We would like to thank the National Natural Science Foundation of China (NSFC 31660008, 31460015) and "Collaborative Innovation Center for Biodiversity and Conservation in the Three Parallel Rivers Region of China" for financial and laboratory support. Zong-Long Luo thanks Dr. Shaun Pennycook from Landcare Research, Auckland, New Zealand, for advising on the taxon name and Jing Yang, Yan-Mei Zhang and Hong-Wei Shen are acknowledged for their help on phylogenetic and morphological work. Jian-Kui Liu thanks Chiang Mai University (Chiang Mai, Thailand) for the offer of a Post-Doctoral Fellowship.

\section{References}

Begerow D, Nilsson H, Unterseher M, Maier W. 2010 - Current state and perspectives of fungal DNA barcoding and rapid identification procedures. Applied Microbiology and Biotechnology 87, 99-108.

Bucher VVC, Hyde KD, Pointing SB, Reddy CA. 2004 - Production of wood decay enzymes, mass loss and lignin solubilization in wood by diverse freshwater fungi. Microbial Ecology 48, 331-337.

Cai L, Tsui CKM, Zhang KQ, Hyde KD. 2002 - Aquatic fungi from Lake Fuxian, Yunnan, China. Fungal Diversity 9, 57-70.

Cai L, Zhang KQ, McKenzie EHC, Hyde KD. 2003 - Freshwater fungi from bamboo and wood submerged in the Liput River in the Philippines. Fungal Diversity 13, 1-12.

Chomnunti P, Hongsanan S, Aguirre-Hudson B, Tian Q et al. 2014 - The sooty moulds. Fungal Diversity $66,1-36$.

Glez-Peña D, Gómez-Blanco D, Reboiro-Jato M, Fdez-Riverola F et al. 2010 - ALTER: programoriented conversion of DNA and protein alignments. Nucleic Acids Research 38, 14-18.

Goh TK, Hyde KD. 1996 - Biodiversity of freshwater fungi. Journal of Industrial Microbiology \& Biotechnology 17, 328-345.

Hall TA. 1999 - Bio Edit: a user-friendly biological sequence alignment editor and analysis program for Windows 95/98NT. Nucleic Acids Symposium Series 41, 95-98.

Ho WH, Hyde KD, Hodgkiss IJ. 2001 - Fungal communities on submerged wood from streams in Brunei, Hong Kong, and Malaysia. Mycological Research 105, 1492-1501.

Hyde KD, Goh TK. 1997 - Fungi on submerged wood in a small stream on Mt Lewis, North Queensland, Australia. Muelleria 10, 145-157.

Hyde KD, Goh TK. 1998a - Fungi on submerged wood in Lake Barrine, north Queensland, Australia. Mycological Research 102, 739-749.

Hyde KD, Goh TK. 1998b - Fungi on submerged wood in the Riviere St Mane-Louis, The Seychelles. South African Journal of Botany 64, 330-336.

Hyde KD, Goh TK, Steinke TD. 1998 - Fungi on submerged wood in the Palmiet River, Durban, South Africa. South African Journal of Botany 64, 151-162.

Hyde KD, Fryar S, Tian Q, Bahkali AH et al. 2016a - Lignicolous freshwater fungi along a northsouth latitudinal gradient in the Asian/Australian region; can we predict the affects of global warming on biodiversity and function? Fungal Ecology 19, 190-200.

Hyde KD, Hongsanan S, Jeewon R, Bhat DJ et al. 2016b - Fungal diversity notes 367-490: taxonomic and phylogenetic contributions to fungal taxa. Fungal Diversity 80, 1-270.

Hyde KD, Norphanphoun C, Abreu VP, Bazzicalupo A et al. 2017 - Fungal diversity notes 603708: taxonomic and phylogenetic notes on genera and species. Fungal Diversity 87, 1-235.

Jeewon R, Hyde KD. 2016 - Establishing species boundaries and new taxa: recommendations to resolve taxonomic ambiguities. Mycosphere 7, 1669-1677. 
Jones EBG, Hyde KD. 1988 - Methods for the study of marine fungi from the mangroves. In: Role of Microorganisms in Nutrient Recycling of Mangrove Soils and Waters (ed. M. Vannucci). UNESCO Publication, India, 9-27.

Katoh K, Standley DM. 2013 - MAFFT Multiple Sequence Alignment Software Version 7: Improvements in performance and usability. Molecular Biology and Evolution 30, 772-780.

Li WL, Luo ZL, Liu JK, Bhat DJ et al. 2017 - Lignicolous freshwater fungi from China I : Aquadictyospora lignicola gen. et sp. nov. and new record of Pseudodictyosporium wauense from northwestern Yunnan Province. Mycosphere 8, 1587-1597.

Liu JK, Hyde KD, Jeewon R, Phillips AJL et al. 2017 - Ranking higher taxa using divergence times: a case study in Dothideomycetes. Fungal Diversity 84: 75-99.

Liu XY, Udayanga D, Luo ZL, Chen LJ et al. 2015 - Backbone tree for Chaetothyriales with four new species of Minimelanolocus from aquatic habitats. Fungal Biology 119, 1046-1062.

Liu YL, Whelen S, Hall BD. 1999 - Phylogenetic relationship among ascomycetes: evidence from an RNA polymerase II subunit. Molecular Biology and Evolution 16, 1799-1808.

Luo J, Yin JF, Cai L, Zhang KQ et al. 2004 - Freshwater fungi in Lake Dianchi, a heavily polluted lake in Yunnan, China. Fungal Diversity 16, 93-112.

Luo ZL, Bao DF, Bhat DJ, Yang J et al. 2016 - Sporoschisma from submerged wood in Yunnan,China. Mycological Progress 15, 1145-1155.

Luo ZL, Bhat DJ, Jeewon R, Boonmee S et al. 2017 - Molecular phylogeny and morphological characterization of asexual fungi (Tubeufiaceae) from freshwater habitats in Yunnan, China. Cryptogamie Mycologie 38, 27-53.

Luo ZL, Hyde KD, Bhat DJ, Jeewon R et al. 2018 - Morphological and molecular taxonomy of novel species Pleurotheciaceae from freshwater habitats in Yunnan, China. Mycological Progress (online). https://doi.org/10.1007/s11557-018-1377-6

Maharachchikumbura SSN, Hyde KD, Jones EBG, McKenzie EHC et al. 2016 - Families of Sordariomycetes. Fungal Diversity 79, 1-317.

Miller MA, Pfeiffer W, Schwartz T. 2010 - Creating the CIPRES Science Gateway for inference of large phylogenetic trees. In Gateway Computing Environments Workshop 2010 (GCE), New Orleans, Louisiana, November 2010, pp 1-8.

Nylander JAA. 2004 - MrModeltest v2.2 Program distributed by the author. Evolutionary Biology Centre, Uppsala University, Uppsala.

Odum EP. 1971 - Fundamentals of ecology. 3rd edn. WB Saunders, Philadelphia, PA.

Page RD. 1996 - TREEVIEW: an application to display phylogenetic trees on personal computers. Computer Applications in the Bioscience 12, 357-358.

Palmer ME, Covich AP, Finlay BJ, Gilbert J et al. 1997 - Biodiversity and ecosystem processes in freshwater sediments. Ambio 26, 571-577.

Rannala B, Yang Z. 1996 - Probability distribution of molecular evolutionary trees: a new method of phylogenetic inference. Journal of Molecular Evolution 43, 304-311.

Ronquist F, Teslenko M, Van der Mark P, Ayres DL et al. 2012 - MrBAYES 3.2: efficient Bayesian phylogenetic inference and model choice across a large model space. Systematic Biology 61, 539-542.

Schoch CL, Sung GH, López-Giráldez F, Townsend JP et al. 2009 - The Ascomycota Tree of Life: A Phylum-wide Phylogeny Clarifies the Origin and Evolution of Fundamental Reproductive and Ecological Traits. Systematic Biology 58, 224-239.

Schoch CL, Seifert KA, Huhndorf S, Robert V et al. 2012 - Nuclear ribosomal internal transcribed spacer (ITS) region as a universal DNA barcode marker for Fungi. Proceedings of the National Academy of Sciences of the United States of America 109, 6241-6246.

Shannon CE, Weaver W. 1963 - The mathematical theory of communication. Urbana (IL): University of Illinois Press.

Shenoy BD, Jeewon R, Wu WP, Bhat DJ et al. 2006 - Ribosomal and RPB2 DNA sequence analyses suggest that Sporidesmium and morphologically similar genera are polyphyletic. 
Mycological Research 110, 916-928.

Sivichai S, Jones EBG, Hywel-Jones NL. 2000 - Fungal colonization of wood in a freshwater stream at Khao Yai National Park, Thailand. Fungal Diversity 5, 71-88.

Stamatakis A. 2006 - RAxML-VI-HPC: maximum likelihood-based phylogenetic analyses with thousands of taxa and mixed models. Bioinformatics 22, 2688-2690.

Stamatakis A, Hoover P, Rougemont J. 2008 - A rapid bootstrap algorithm for the RAxML webservers. Systematic Biology 75, 758-771.

Su HY, Udayanga D, Luo ZL, Manamgoda D et al. 2015 - Hyphomycetes from aquatic habitats in Southern China: Species of Curvularia (Pleosporaceae) and Phragmocephala (Melanommataceae). Phytotaxa 226, 201-216.

Su HY, Hyde KD, Maharachchikumbura SSN, Ariyawansa HA et al. 2016 - The families Distoseptisporaceae fam. nov., Kirschsteiniotheliaceae, Sporidesmiaceae and Torulaceae, with new species from freshwater in Yunnan Province, China. Fungal Diversity 80, 375-409.

Swofford DL. 2002 - PAUP 4.0b10: Phylogenetic Analysis Using Parsimony. Sinauer Associates, Sunderland.

Tanaka K, Hirayama K, Yonezawa H, Sato G et al. 2015 - Revision of the Massarineae (Pleosporales, Dothideomycetes). Studies in Mycology 82, 75-136.

Tsui CKM, Hyde KD, Hodgkiss IJ. 2000 - Biodiversity of fungi on submerged wood in Hong Kong streams. Aquatic Microbial Ecology 21, 289-298.

Tsui CKM, Hyde KD, Hodgkiss IJ. 2001 - Colonization pattern of wood-inhabiting fungi on baits in Hong Kong rivers, with reference to the effects of organic pollution. Antonie van Leeuwenhoek 79, 33-38.

Tsui CKM, Hyde KD, Hodgkiss IJ. 2003 - Methods for investigating the biodiversity and distribution of freshwater ascomycetes and anamorphic fungi on submerged wood. Fungal Diversity Research Series 10, 195-209.

Vijaykrishna D, Jeewon R, Hyde KD. 2005 - Fusoidispora aquatica: A new freshwater ascomycete from Hong Kong based on morphology and phylogeny inferred from rDNA gene sequences. Sydowia 57, 267-280.

Vilgalys R, Hester M. 1990 - Rapid genetic identification and mapping of enzymatically amplified ribosomal DNA from several Cryptococcus species. Journal of Bacteriology 172, 4238-4246.

White TJ, Bruns T, Lee S, Taylor JL. 1990 - Amplification and direct sequencing of fungal ribosomal RNA genes for phylogenetics. In: Innis MA, Gelfand DH, Sninsky JJ, White TJ (Eds.) PCR protocols: a guide to methods and applications. Academic Press, pp. 315-322.

Wong MKM, Goh TK, Hodgkiss IJ, Hyde KD et al. 1998 - Role of fungi in freshwater ecosystems. Biodiversity \& Conservation 7, 1187-1206.

Wu WP, Zhuang WY. 2005 - Sporidesmium, Endophragmiella and related genera from China. Fungal Diversity Research Series 15, 1-351.

Xia JW, Ma YR, Li Z, Zhang XG. 2017 - Acrodictys-like wood decay fungi from southern China, with two new families Acrodictyaceae and Junewangiaceae. Scientific Reports 7, 7888.

Yang J, Maharachchikumbura SSN, Liu JK, Hyde KD et al. 2018 - Pseudostanjehughesia aquitropica gen. et sp. nov. and Sporidesmium sensu lato species from freshwater habitats. Mycological Progress 17, 591-616.

Yuen TK, Hyde KD, Hodgkiss IJ. 1998 - Physiological growth parameters and enzyme production in tropical freshwater fungi. Material und Organismen 32, 2-16.

Zhu D, Luo ZL, Baht DJ, McKenzie EHC et al. 2016 - Helminthosporium velutinum and $H$. aquaticum sp. nov. from aquatic habitats in Yunnan Province, China. Phytotaxa 253, 179190. 